\title{
Determinants of Income Inequality in Indonesia: Case Study of 33 Provinces in 2011-2016
}

\author{
Candra Fajri Ananda \\ Brawijaya University \\ Abdul Manap Pulungan \\ Institute for Development of Economics and Finance
}

This study intends to determine factors that influence income inequality in Indonesia based on regional data. The independent variables are macroeconomic (economic growth, unemployment, and inflation), fiscal (expenditure) and financial (the tradable credit). By applying the fixed effect panel framework, the study concludes that macroeconomic and fiscal factors have a significant impact on income inequality. In contrast to previous studies, the impact of economic growth on income inequality is positive. On the other hand, the fiscal variable has no impact on income inequality as most regional expenditures are used for unproductive purposes, such as payroll, goods, and services.

Keywords: Inequality, Macroeconomic, Fiscal, Financial

\section{INTRODUCTION}

Inequality is an important issue in the development of a country as it has adverse economic and social impacts (Gonzales and Menedez, 2000). Economically, a widening and continuing income disparity will adversely affect economic performance in the long run (Stiglitz, 2015). Economic growth will be less than its potential as it is not driven by all layers of society. Socio-politically, a widening gap can lead to increased crime, unrest, or even revolution. All of these conditions undermine economic growth (Lee and Son, 2016).

Income inequality does not only occur in emerging economies, but also in developed countries. However, escalation of income inequality in the emerging economies is a matter of concern since their contribution to the global economy has increased after the 2008 global financial crisis. As an emerging economy, Indonesia has achieved decent economic growth that has contributed to reducing poverty and unemployment. Nevertheless, income inequality remains high and government must exert more efforts to achieve its objective of reducing inequality as stated in the National Medium-Terms Development Plan 2015-2019.

There are different data that show how inequality has developed in Indonesia. First, Indonesia measures inequality from the expenditure side (the Gini ratio). Statistics Indonesia publishes the Gini ratio data twice a year, both in urban and rural areas. In September 2018, the Gini ratio in Indonesia was 
0.384 overall, 0.391 in urban and 0.319 in rural areas (Statistics Indonesia, 2018). The RPJMN has set to achieve a Gini ratio of 0.36 in 2019.

Second, data on inequality also uses the income approach. Credit Suisse (2018) revealed that 1 percent of Indonesia's richest control about 46.6 percent of the nation's wealth. Globally, Indonesia is the sixth highest after Thailand (66.9 percent); Russia (57.1 percent); Turkey (54.4 percent); India (51.1 percent) and Africa (48.7 percent). The average for Asia-Pacific region for wealth controlled by the top one percent is 40.6 percent; while in Europe it is 39.7 percent.

The government has made some efforts to reduce income inequality since long time ago. In 1974, for instance, the government adopted Repelita II (the Second Five-Year Economic Development Plan) that aimed to increase the livelihood and welfare of everyone. The government followed the 'Development Trilogy' doctrine, namely "equitable development towards achieving social justice, high economic growth and a healthy and dynamic national stability". Some of the championed programs included rural development through 'new style' labor intensive projects, the development of non-agricultural enterprises, rural credit development project, district-level development projects, regreening and reforestation projects. It also included Village Development Assistance in 1969/70 amounting to IDR 100,000 per village, which was increased to IDR 350,000 per village in 1978/79 (Bappenas, 1979). Repelita II lead to the decline in the percentage of the poor and inequality, from 60 percent in 1970 to 33.3 percent in 1978, and further declined from 0.38 in 1978 to 0.33 in 1980 . The government's ability to achieve development targets in Repelita II was closely related to the rise in global oil price in 1976, which increased state revenue.

Indonesia's economy showed promising development throughout Repelita I-IV, but was curtailed significantly due to the financial crisis of 1997/98. The crisis resulted in an increase of poverty from 17.47 percent in 1996 to 24.2 percent in 1998. The Gini ratio actually dropped as incomes overall decreased. The Gini ratio in 1996 was 0.35 dropping to 0.31 in 1999. Along with the financial and social crises that unfolded, the pressure towards regional autonomy increased. In 2001, regional autonomy was officially implemented. Slowly, the central government transfers to regions increased. Since then, the Gini ratio has tended to increase. In 2002, the Gini ratio was 0.32 , increasing to 0.34 in 2005 and 0.38 in 2010 , peaking at 0.41 .

Apart from regional autonomy, the government also instituted the Village Funds policy through the 2014 Village Law. This was intended to improve public services, reduce poverty, advance the village economy, address inter-village disparity, and strengthen rural communities as subjects of development (Ministry of Finance, 2017).

\section{LITERATURE BACKGROUND}

\section{Income Inequality and Fiscal Decentralization}

Proponents of fiscal decentralization believe that this strategy can reduce regional disparity as it promotes more equitable distribution through transfer of funds from the central government. Furthermore, it is also believed that decentralization promotes efficiency and equity. Decentralization can reduce inequality in regions as the central government distributes its authority to the sub-national level including budget. Through the transfer of funds and authority, sub-national governments can more freely implement programs, although in reality the political, factional and group interests are not always consistent with the needs of development in regions. Apart from that, development programs are still prescribed from the central government (top-down), and are often difficult to implement in the regions.

The results presented in the paper by Irawan (2014) revealed that greater fiscal decentralization reduced regional disparity. This study also highlighted that development of fiscal expenses, manufacturing, infrastructure, urban concentration, and public-sector size have had a significant influence on income inequality in 33 provinces in Indonesia.

On the other hand, decentralization contributes to higher spatial inequality due to the fact that: (i) the bargaining power of rich regions to influence the central government is relatively higher than poor regions, (ii) rich regions are more attractive to investors than poor regions due to significant differences in 
resources. Irawan (2014) posited that decentralization increased regional disparity due to potential costs associated with institutional capacity, quality of government and social-economic endowment. There are two reasons why spatial inequality or regional disparity is of concern to both central and regional governments: (i) it influences the overall inequality, and (ii) it has a detrimental impact on society, social and political stability.

\section{Income Inequality and Economic Growth}

Economic development is associated with changes in inequality (Kuznets 1995 in Sagala et al, 2013). Kuznets explained that income inequality tends to increase in the first stages of economic development, to later plateau, and then decrease. Kuznets noted that income inequality tends to soften when the share of non-agricultural sector increases.

Several studies arrive at different results and conclusions regarding the relationship between inequality and economic growth. Forbes (2000) found positive impact of economic of high income household and the lower on income group. On the other hand, Son and Lee (2016) concluded a negative relationship.

There are three theoretical frameworks that underlie the negative relationship between income inequality and economic growth (Lee and Son, 2016). The first is the credit market imperfection theory that elaborates the number of bottlenecks faced by the low-income families to access the financial sector. As these income groups have limited access to both formal and informal credit markets, the families remain in the lower-income.

The second theory is based on political economy theories where economic inequality leads to distorted redistribution. This circumstance may decrease workforce incentives and slow down economic growth. Finally, the third theory is the perspective of sociopolitical instability of the state which concludes that there is a relation between greater inequality in wealth and unlawful action (such as crime, rioting, and revolution) resulting instability and hampers long-run economic growth.

\section{Income Inequality and the Financial Sector}

The financial sector plays an important role to mitigate income inequality through economic growth. However, it requires a well-developed financial sector that offers inexpensive credit. Entrepreneurial activity, for instance, can create employment opportunities, increase economic growth, cuts income inequality when there is support from the financial sector. The financial sector may offer more sources of liquidity to businesses so they no longer need to depend on internal financial resources (self-finance). For poor families, access to financial institutions also allows them to improve human capital with investments in health and education (Younsi and Bechtini, 2018).

The Gini coefficient may also increase due to financial development. During the first stages of financial development, the cost to access the financial sector is relatively expensive for the poor. Consequently, the financial development benefits are only limited to the rich. When obtaining credit, the poor face higher interest rates due to risk profiling, requiring them to provide more collateral to guarantee the credit. The poor are also compelled to follow cumbersome procedures and requirements, such as surveys and insurance.

In Vietnam, there was evident that demonstrate how the impact of financial development and education with the declining of income inequality (Hoi and Hoi, 2013). The financial development opens a credit access for several purposes such as education for the low-income groups. A research by Liang (2016) in China concludes that financial development has fundamental impacts on the income distribution pattern in the post-reform period. Liang noted that income inequality in urban area decline due to financial development. However, the advantages of financial development severely reduced by massive layoffs and urban unemployment as radial urban reform and restructuration of state-owned enterprises.

In addition to investigate the financial role in reducing income inequality, Burgess and Rohini (2005) conducted a study in India. The finding showed that there was relationship among an increasing of rural banks to income distribution and total per capita output. It was quite unique in India where in between 1977 and 1990 the central bank mandated the commercial bank could open a branch in a location (one or 
more) if it opens for in locations with no bank branches. As a result, commercial bank expanded its branches to the area with initial financial development. The study noted that program of rural branch expansion in India significantly reduced rural poverty and at the same time increased non-agricultural output. Nevertheless, Fowowe and Abidoye (2013) found that financial development has no impact on poverty and inequality in African countries. The study examined the impact of financial development, as gauged by private credit and broad money (M2), on poverty and inequality in African countries. On the other hand, macroeconomic variables such as low inflation as well as trade openness significantly reduced poverty and inequality levels.

\section{Income Inequality and Inflation}

There are various channels that describe the consequences of inflation on income distribution. The first channel is through the ability to fulfill cost of living. Although the level of inflation remains the same both for the rich income group and the lower group, but the latter suffer more than other (Laidler and Parkin, 1975). This happened as more than 50 percent of the lower income group expenses for foods. As a result, the inflation rate impact to wider income inequality. Li and Zou (2002) explained the relationship between inflation and income inequality can usually be traced from the wage growth. In developing and emerging economies, the growth of wages is often lower than inflation.

Christaensen and Demery (2006) posited that wages could not directly adjust food prices, so that real wages tend to decline in the midst of higher inflation. Since most of the income of the lower-income households is dedicated to food, their ability to move forward from the bottom income categories is much more handicapped. Wodon and Zaman (2008) argued that the impact of food prices on households depends on net consumption.

Walsh and $\mathrm{Yu}$ (2012) examined the impact of food inflation and non-food inflation (e.g. education) on income inequality in China. It is clear that, in general, food prices adversely impact poor households, especially in urban areas. However, the impact is positive in rural regions. In India, this study concluded that non-food inflation aggravated income inequality both in urban and rural areas, while food inflation worsens income inequality in rural areas.

The second transmission of inflation impact to income inequality passes through the monetary and financial mechanism. In the case of high inflation rate, the central bank adjusts its interest benchmark and impact to lending rate in the commercial banks. As the low income group has a poor credit profile, the commercial bank adjusts the interest rate higher than the upper income group. As a result, credit disbursement to the low income group remains limited.

\section{Income Inequality and Unemployment}

There two perspectives how literature links the relationship between unemployment and inequality namely: (i) unemployment and inequality reaction due to changes in the fundamentals of the economy, such as trade or technological shock; and (ii) the impact of changes in unemployment on income inequality. Acemoglu (2009) explained that the industry tended to recruit all workers (skilled and unskilled) where there are few skilled workers in the economy and the gap of productivity between skilled and unskilled is quite small. Inequality in wage takes place where the proportion skilled workforces in industry increase gradually. The labor-market development theory explains that there is a qualitative change in the composition of jobs due in response to technology development. As a result, unskilled workforces may be replaced by machines or low-wage jobs.

Mocan (1999) explored the US economic data between 1947 and 1974 to identify the relationship between macroeconomic and income distribution. The study concluded that income inequality was countercyclical in its behavior. The position of the low-income groups in the labor market weakened when unemployment increases. From 1949 to 1994, the income share of the bottom three quintiles and the second highest quintile was reduced due to an increase in structural unemployment.

Sheng (2011) also took the study case in the US to investigate the relationship between unemployment and income inequality between 1941 and 2010. The study found a positive relationship between unemployment and income inequality. Soaring unemployment is among the reasons behind the 
rising income inequality. The study revealed a tradeoff between the changing rates of unemployment and the wage share. Thus, the wage share in aggregate personal income becomes a proxy for income inequality.

Tregenna (2011) examined the extent to which changes in the unemployment rate impacted income inequality in South Africa. The study revealed that employment status was at the center among the determinants of income inequality levels and trends. The share of workforces in the formal and informal sectors, however, had little impact in explaining income inequality. Wage inequality has increased due to changes in the demand for skilled workers as compared to unskilled workers. The trend has been consistent in 1980s and 1990s as the workers' intellectual skills have grown to become far more important than physical strength in the labor market. Naturally, the income of unskilled workers has tended to decrease compared to that of educated workers. During high inflation, it is unskilled workers that would suffer the most.

\section{MODEL SPECIFICATION AND ESTIMATION RESULT}

The study employs five independent variables to investigate their impact on income inequality in Indonesia from 2011 to 2016 based on data of 33 provinces. The inflation rate (inf), economic growth (growth), and unemployment rate $(\mathrm{u})$ are the macroeconomic variables, while the share of the tradable sector credit to total provincial credit (stdc) and total expenditure (lnte) are the financial sector and the fiscal sector variables, respectively.

TABLE 1

ESTIMATION RESULT

\begin{tabular}{|l|l|c|c|c|}
\hline Variable & Remaks & $\begin{array}{c}\text { Expected } \\
\text { sign }\end{array}$ & Coefficient & Prob. \\
\hline gini & gini ratio (index) & & & \\
\hline $\mathrm{c}$ & constanta & & 0.3698 & \\
\hline inf & inflation (year on year, \%) & + & 0.0013 & $0.0104^{*}$ \\
\hline growth & economic growth (year on year, \%) & $+/-$ & 0.0026 & $0.0472^{*}$ \\
\hline stdc & $\begin{array}{l}\text { share of tradable sector credit to total province's } \\
\text { credit (\%) }\end{array}$ & + & -0.0007 & $0.0636^{* *}$ \\
\hline $\mathrm{u}$ & unemployment rate (\%) & + & 0.0025 & $0.0970^{* *}$ \\
\hline lnte it $_{\text {t }}$ & total expenditure (ln) & - & -0.0014 & 0.5491 \\
\hline$\varepsilon_{\text {it }}$ error term & 0.810705 & & \\
\hline Adjusted R-squared & $0.000000^{*}$ & & \\
\hline Prob(F-statistic) & 1.862369 & & \\
\hline Durbin-Watson stat & & \\
\hline
\end{tabular}

*sig 5 percent; **sig 10 percent

The study applied the fixed effect panel estimation framework to identify the particular characteristics of the 33 provinces. The estimation results concluded that inflation and growth are significant at 5\%, while the share of credit of the tradable sector to the total provincial credit and unemployment are significant at $10 \%$. On the other hand, there is no significant relationship between regional expenditure and the Gini ratio in this study.

For the period of 2011 to 2016 , the Gini ratio nationally has increased by 0.01 , from 0.388 to 0.394 . Data released by Statistics Indonesia (2017) reveals that the total expenditure contribution of the $40 \%$ lowest group has decreased by $0.56 \%$ between 2011 and 2016, from $17.67 \%$ to $17.11 \%$. On the other hand, the share of the middle $40 \%$ group and the top $20 \%$ group increased by $0.44 \%$ and $0.11 \%$ 
respectively. In 2014, the ratio peaked as the contribution of the lowest $40 \%$ income group bottomed that year.

TABLE 2

DISTRIBUTION OF EXPENDITURE PER CAPITA AND GINI RATIO IN PERIOD OF 2011-2016

\begin{tabular}{|l|c|c|c|c|}
\hline & $40 \%$ lowest & $40 \%$ intermediate & $20 \%$ highest & gini ratio \\
\hline 2011 & 17.67 & 35.89 & 46.45 & 0.388 \\
\hline 2012 & 16.88 & 34.18 & 48.94 & 0.413 \\
\hline 2013 & 17.25 & 34.25 & 48.50 & 0.406 \\
\hline 2014 & 16.48 & 34.83 & 48.69 & 0.414 \\
\hline 2015 & 17.45 & 34.70 & 47.84 & 0.402 \\
\hline 2016 & 17.11 & 36.33 & 46.56 & 0.394 \\
\hline $2011-2016$ & -0.56 & 0.44 & 0.11 & 0.01 \\
\hline
\end{tabular}

Source: Statistics Indonesia, 2017

The relationship between inflation and the Gini ratio in this study is in line with earlier studies. During the study period, there were circumstances that pushed inflation to a high level, particularly from an increasing of the global oil price. According to data of BP Statistical Review of World Energy (2018) the oil price moved from average US\$79 per barrel in 2010 to average US\$107 per barrel in 2012. In 2013 , oil price was US\$106 per barrel in average and gradually declined to below US\$100 per barrel in 2014.

In respond to the oil price movement, the government decided to adjust the domestic fuel price during 2013 to 2015 in order to lessen the fuel subsidy budget. As the major components of inflation, the adjustment of fuel price pushed inflation rate significantly. The headline inflation reached above 8 percent in 2013 and 2014, respectively, whereas the inflation of administered price was excess 15 percent and the volatile food inflation was higher than 10 percent.

After rocketing in 2013 and 2014, the headline inflation gradually declined in the period of 2015 to 2016, but the volatile food inflation remains high, mainly in staple food price. According to the data used in this study, 23 provinces had staple food inflation exceeding the headline inflation. In 2016, the staple food inflation in North Sumatra was $15.55 \%$ (yoy), about $9 \%$ above the headline inflation. Higher inflation has a harmful effect on real wages of the lowest income group. In 2013, for example, real wages of farmers decreased by $1.94 \%$ while the inflation rate was $9.38 \%$. This circumstance kept the lower income group trapped at the bottom of the pyramid. Since the lowest income group only has cash, the value of any money they have will decline in the case of inflation. This situation is different to that of the middle and the highest income group, because they can diversify their wealth holdings into different instruments, such as gold, government bonds, and time-deposits. 


\section{FIGURE 1 \\ HEADLINE INFLATION AND STAPLE FOOD INFLATION IN 33 PROVINCES IN 2016}

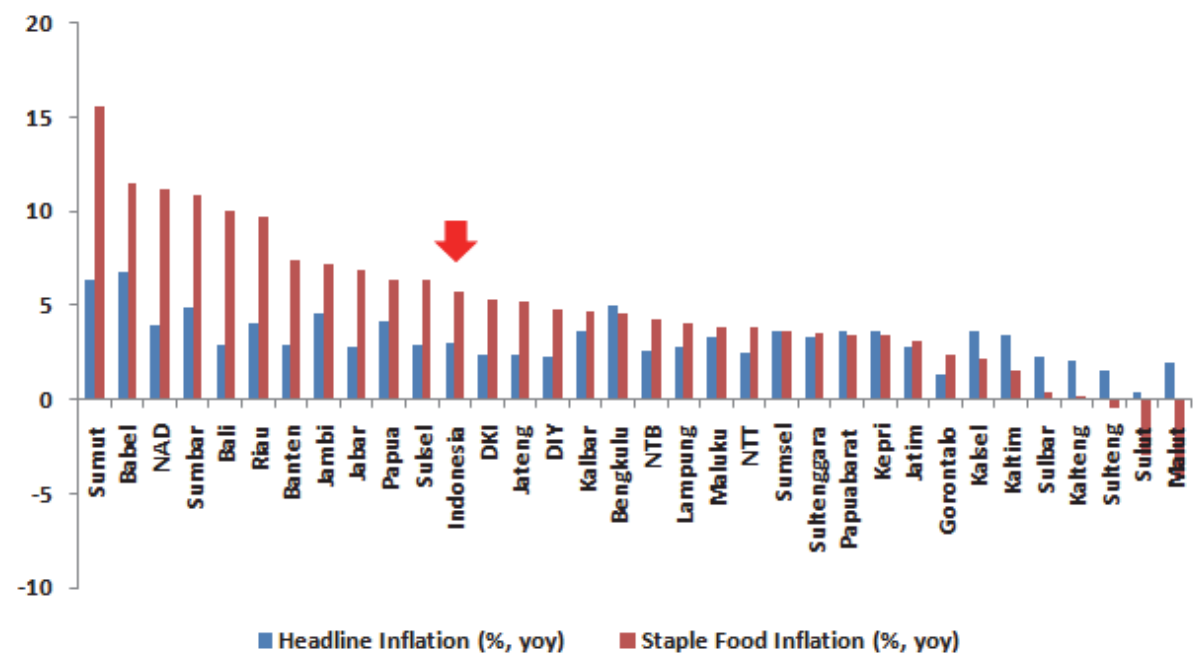

Source: calculated by authors from Statistics Indonesia, 2017

As stated in literatures, the impact of inflation to income inequality can be traced from the wage movement for the low income workforce. In 2013, the growth of the farmer labor daily wages (real) declined 1.94 percent (yoy), whereas the inflation rate was $8.38 \%$. On the other hand, the regional minimum wages went up about $19 \%$ (yoy). Another measurement of inflation impact to income inequality is the commercial bank interest rate depicting how the monetary policy transmits to lending rate. In prior to the hiking of inflation rate in 2013, the benchmark interest rate in Indonesia was 5.75\% in 2012 and moved to $7.5 \%$ in 2013. Between 2012 and 2013, the lending rate for the working capital and investment move about 64 basis point (bps) and 55 bps to $12.14 \%$ and $11.83 \%$, respectively.

The study concluded that economic growth increased income inequality. There two reasons explaining the relationship between economic growth and income inequality in this study. First, the main engine of economic growth in Indonesia is non tradable sectors known as capital incentive that has limit to absorb employment. In Statistics Indonesia, there are 18 non tradable sectors that grew about 6.6 percent in average during 2011 to 2016. On the other hand, the growth of tradable sector (agriculture, mining, and manufacturing) was only 3.4 percent in the period 2011 to 2016 that was lower than the economic growth by 5.03 percent yearly. In fact, the share of employment working in tradable sector achieved approximately 49 percent in average in the period of 2011-2016.

Moreover, most of employment in the tradable sector is low income group, especially in the agriculture sector that reach about 30 percent from national employment. In the details, there are 12 provinces which the tradable sector contributed more than 50\%. The economy of Riau, for instance, had a $75 \%$ contribution from the tradable sector with a growth of about $1.4 \%$ (yoy). Second, there is a high dependency of Indonesian economic growth on commodity price such as crude palm oil (CPO), crude oil, as well as coal. For instance, East Kalimantan, Riau, and Papua connect with the movement of oil and coal price, whereas Jambi links with CPO's price.

The financial sector also contributed to the reduction of income inequality. However, the financial role in Indonesia remained low to boost economic growth. First, the share of commercial banking credit to Gross Domestic Product (GDP) was lower than 50\% that is quite far from the ideal level of 100\%. Second, the share of credit to the micro, small, and medium (MSM) enterprise was only about 7\% of GDP where about $60 \%$ of Indonesia's GDP is contributed by these sectors. Third, the government initiation to push credit for the low income group does not meet the target. Since 2017, the government has introduced the microcredit programs (Kredit Usaha Rakyat, KUR). The KUR scheme is more flexible since the 
borrowers do not need the collateral. The policymakers also cut the KUR interest rate from 22\% in 2014 to $7 \%$ in 2018 . However, the KUR allocation is primarily to the trade and service sectors, whereas the agriculture sector only received the least. Finally, there is imbalance structure between the economic structure and credit structure in the province. In 2016, for instance, the share of tradable credit to total credit in North Maluku was only 1.44\%, while the economic contribution of these sectors is about 39\%.

The study concluded that the level of unemployment influenced the income inequality. In the period of study, unemployment rate gradually declined in the national level. Nevertheless, the workforce sector in Indonesia still face some challenges, namely: (i) the quality of the workforce remained low as the share of lower education employment was close to $60 \%$; (ii) agriculture, forestry, and fisheries absorbed about $30 \%$ of the workforce amid their declining performance; (iii) about $58 \%$ of the employment continues to be in the informal sectors which are very vulnerable since these sectors have no income inflation adjustment, economic and social security.

The total regional budget expenditures have been insignificant to reduce income inequality, because it is dominated by current expenditure such as for personnel, goods, and services. The impact of current expenditure to lessen inequality is limited, while, on the other hand, the share of capital expenditure in the regional budget remained relatively low. In 2016, there was a marked increase in the budget for capital expenditure allocated to fixed assets such as land, machinery, offices, instead of roads, irrigation, and networks. The type of budget allocation is very important for the poor income group, in particular farmers. The capital expenditure portion that is used for roads, irrigation, and network purposes is $37 \%$, whereas about $57 \%$ was for other fixed assets.

According to provincial level data, only two provinces (West Sulawesi and North Maluku) had a capital budget share higher than $30 \%$ of the total budget. Nevertheless, budget disbursement remained low. In North Maluku, for instance, the disbursement of capital budget was merely $67 \%$ in 2016 . The lowest capital budget share of the total regional budget was found in East Java, at only $9.69 \%$, followed by West Java and North Sumatera, at about $12.4 \%$ and $12.49 \%$.

\section{FIGURE 2}

\section{SHARE OF CAPITAL BUDGET TO PROVINCE'S BUDGET AND ITS DISBURSEMENT IN 2016}

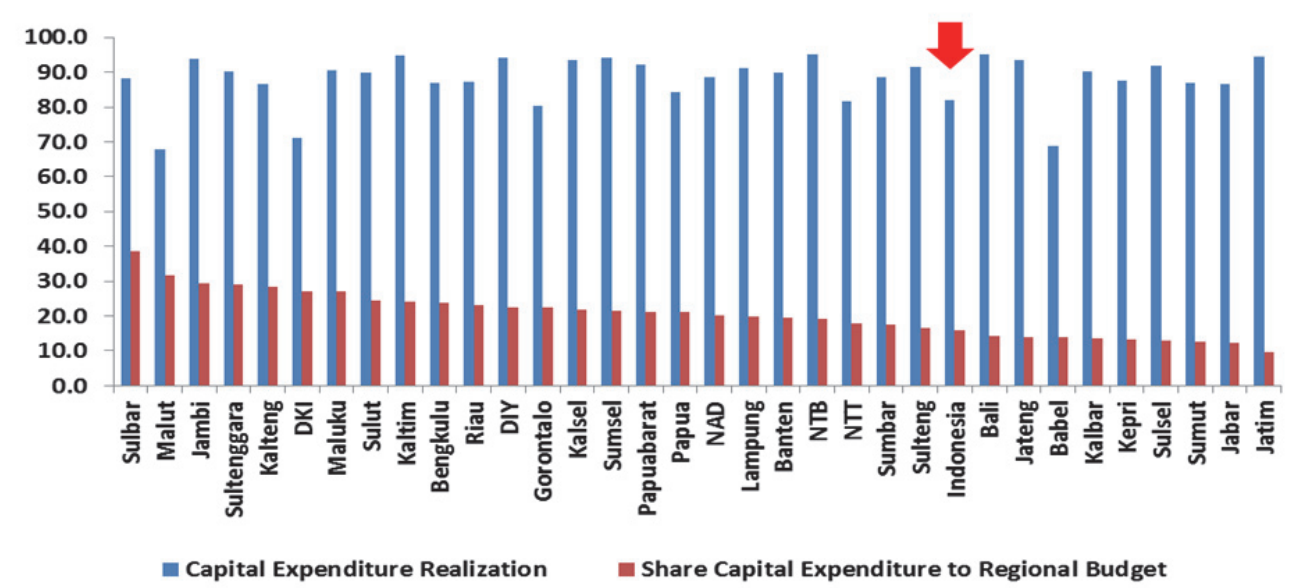

Source: calculated by authors from Statistics Indonesia, 2017 


\section{POLICY RECOMMENDATIONS}

This study recommends the following:

1. The government needs to keep the pace of inflation rate, particularly for the staple food categories such as rice since it impacts on income inequality. In addition, the lower the rate of inflation has an impact on the financing of the interest rate.

2. The government maintains the performance of the tradable sector as this is very important for the province's economic growth, workforce absorption, and income inequality.

3. The government should allocate more budgets to capital purposes, in particular for roads, irrigation, and networking instead of personnel expenditure.

\section{REFERENCES}

Acemoglu, D. (1999). Changes in Unemployment and Wage Inequality: An Alternative Theory and Some Evidence. The American Economic Review, 89(5), 1259-1278.

Bappenas. (1979). Rencana Pembangunan Lima Tahun Ketiga 1979/80-1983/84.

BP. (2019). BP Statistical Review of World Energy: $68^{\text {th }}$ Edition. Retrieved from https://www.bp.com/content/dam/bp/business-sites/en/global/corporate/pdfs/energyeconomics/statistical-review/bp-stats-review-2019-full-report.pdf

Burgess, R., \& Pande, R. (2005). Do Rural Banks Matter? Evidence from the Indian Social Banking Experiment. American Economic Review, 95(3), 780-795.

Christiaensen, L., \& Demery, L. (2006). Down to Earth: Agriculture and Poverty Reduction in Africa. Directions in Development, 38781. Washington DC. The World Bank.

Credit Suisse. (2018, October). Global Wealth Report 2018. Credit Suisse Research Institute.

Forbes, K. J. (2000). A Reassessment of the Relationship between Inequality and Growth. American Economic Association, 90(4), 869-887.

Fowowe, B., \& Abidoye B. (2013). The Effect of Financial Development on Poverty and Inequality in African Countries. The Manchester School. University of Manchester, 81(4), 562-585.

Gonzales, M., \& Menendez, A. (2000). The Effect of Unemployment on Labor Earnings Inequality: Argentina in the Nineties. Working Papers, 216. Princeton University, Woodrow Wilson School of Public and International Affairs, Research Program in Development Studies.

Hoi, L. Q., \& Hoi, C. M. (2013). Financial Sector Development and Income Inequality in Vietnam: Evidence at the Provincial Level. Journal of Southeast Asian Economies (JSEAE), 30(3), 263277.

Hongyi, L., \& Heng-fu, Z. (2002). Inflation, Growth, and Income Distribution: A Cross-Country Study. CEMA Working Papers, 85. China Economics and Management Academy, Central University of Finance and Economics

Irawan, A. (2014). Regional Income Disparities in Indonesia: Measurements, Convergence Process, and Decentralization. Dissertation. University of Illinois at Urbana-Champaign.

Laidler, D., \& Parkin, J. M. (1975). Inflation: A Survey. Economic Journal, Royal Economic Society, 85(340), 741-809.

Lee, D. J. \& Son, J. C. (2016). Economic Growth and Income Inequality: Evidence from Dynamic Panel. Journal Global Economic Review: Perspectives on East Asian Economies and Industries, 45(4).

Ministry of Finance of Republic Indonesia. (2017). Buku Saku Dana Desa. Retrieved from https://www.kemenkeu.go.id/media/6750/buku-saku-dana-desa.pdf

Mocan, N. (1999). Structural Unemployment, Cyclical Unemployment, and Income Inequality. The Review of Economics and Statistics, 81(1), 122-134.

Sagala, P., Takahiro A., \& Yusuf A.A. (2013). Urbanization and Expenditure Inequality in Indonesia: Testing the Kuznets Hypothesis with Provincial Panel Data. Letters in Spatial and Resource Sciences, 7(3), 133. 
Sheng, Y. (2011). Unemployment and Income Inequality: A Puzzling Finding from the US in 1941-2010. Retrieved from https://ssrn.com/abstract=2020744 or http://dx.doi.org/10.2139/ssrn.2020744

Statistics Indonesia. (2018). Inequality of Population Expenditure in Indonesia September 2017. Statistic Indonesia Release No. 06/01/Th. XXI.

Statistics Indonesia. (2019). Inequality of Population Expenditure in Indonesia September 2018. Statistic Indonesia Release No. 08/01/Th. XXII.

Stiglitz, E. J. (2015). Inequality and Economic Growth. Rethinking Capitalism, 86(S1), 134-155.

Tregenna, F. (2011). Earnings inequality and unemployment in South Africa. International Review of Applied Economics, 25(5), 585-598.

Walsh, J. P., \& Yu, J.Y. (2012). Inflation and Income Inequality: Is Food Inflation Different? IMF Working Paper, 12/147. Retrieved from https://www.imf.org/external/pubs/ft/wp/2012/wp12147.pdf

Wodon, Q., \& Zaman, H. (2008). Rising Food Prices in Sub-Saharan Africa: Poverty Impact and Policy Responses. Policy Research Working Paper, 4738. The World Bank.

Younsi, M., \& Bechtini M. (2018). Economic Growth, Financial Development and Income Inequality in BRICS Countries: Evidence from Panel Granger Causality Tests. Munich Personal RePEc Archive Paper, 85384.

Zhicheng L. (2006, December). Financial Development and Income Distribution: A System Gmm Panel Analysis with Application to Urban China. Journal of Economic Development, Chung-Ang Unviersity, Department of Economics, 31(2), 1-21. 